\title{
The Economic Impact Of International Trade In A Small Regional Economy: The Case Of Miami, Florida
}

Robert David Cruz, (E-mail: rdcruz@bellsouth.net), Barry University

\begin{abstract}
This study estimates the economic impacts from international trade activity in Miami-Dade using an input-output model developed with IMPLAN software. Common observations suggest that international trade is an important determinant of the long-term economic growth of the metro area's economy, as well as a key factor in the region's pattern of short-run business cycles. The logistics of international trade requires not only port operations, but also involves numerous components of the transportation network. Local manufacturing firms are also likely to be involved in exporting or production requiring imported intermediate goods. BLS establishment survey data is used to identify the direct employment and labor compensation in industries that are directly involved in the movement of international cargo. Census data on origin of exports is used to estimate the direct impact of international trade related local manufacturing. An economic model for Miami-Dade County is then used to estimate the local indirect and induced impacts of international merchandise trade.
\end{abstract}

\section{INTRODUCTION}

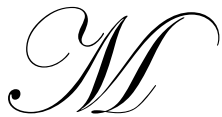

iami-Dade County is a U.S. commercial gateway to South America and the Caribbean. The Miami Customs District handles the largest share of the nation's overseas shipments of exports and imports to South America and the Caribbean from among the nation's customs regions. Twentyfour percent of total U.S. trade with South America was shipped through the Miami Customs District, but nearly 40 percent of U.S. exports to that region were shipped through Miami in 2002. Fifty-two percent of U.S. exports to Central America (does not include Mexico) and a nearly equivalent share of U.S. imports was shipped through this custom's district as well. Approximately 45 percent of U.S. exports to the Caribbean were shipped through Miami, while one third of imports to that region were shipped through Miami. (See Table 1.)

\begin{tabular}{|l|c|c|c|}
\hline \multicolumn{4}{|c|}{ Table 1: Miami Customs District Percentage of U.S. Trade with Regions, 2002 } \\
\hline Region & Exports & Imports & Total Trade \\
\hline South America & $38.70 \%$ & $14.40 \%$ & $23.60 \%$ \\
\hline Central America & $52.40 \%$ & $55.70 \%$ & $54.10 \%$ \\
\hline Caribbean & $45.20 \%$ & $33.00 \%$ & $39.70 \%$ \\
\hline Source: U.S. Census Bureau, Foreign Trade Statistics \\
\hline
\end{tabular}

Miami International Airport and the Port of Miami, both located in Miami-Dade County, Florida, handle the bulk of the District's trade shipments and billions of dollars worth of international cargo are shipped each year through these two ports. ${ }^{1}$ By 2003 nine million tons of cargo was loaded or unloaded from Port of Miami docks, while nearly 1.5 million tons of international air cargo were shipped through Miami International Airport (MIA).

\footnotetext{
${ }^{1}$ The Miami Customs District also includes Port Everglades in Ft. Lauderdale and the Port of Palm Beach. Both ports are small in comparison to the cargo volume and value shipped through the Port of Miami. Miami International Airport is one of busiest airports in terms of cargo in the nation (ranked $4^{\text {th }}$ in 2003).
} 
International trade has long been recognized as a major regional economic engine, affecting both long-term economic trends and cyclical fluctuations. Substantial growth in international trade was experienced during the 1970s and 1980s, and this trend continued into the boom years of the 1990s. International air cargo volumes grew by 160 percent between 1970 and 1980, while ocean cargo increased by 215 percent over that same period. International air cargo grew by 70 percent during the decade of the 1980 s, while ocean cargo grew by 44 percent over that same period. International cargo handled through the Port of Miami and through MIA rose sharply after 1990 reflecting a more favorable international trade environment, as well as significant public sector investments in both the airport and the seaport. Between 1990 and 2000 the Port's cargo volume increased by 117 percent, while the volume of international cargo at MIA increased by 107 percent over that 10-year period.

The growth in aggregate employment followed a trend similar to that observed in international cargo activity. During the decade of 1970s, total employment grew by 40 percent, but the pace of employment growth (like the growth in international cargo) decelerated significantly during the 1980s when it grew by just 18 percent. The pace of total employment growth accelerated in the 1990s. Between the recession of 1991 to the local business cycle peak in 2001, employment grew by 241,000 jobs compared with a job gain of 163,000 from 1980 to $1990 .^{2}$

While the long-term data reflects a direct correlation between international cargo and aggregate employment, the correlation between fluctuations in employment and cargo is less clear. (See Table 2.) The shortlived U.S. recession of 1980 did not register at all in the Miami-Dade economy, and employment grew solidly that year. Cargo activity similarly continued to register gains that year. In the recession of 1982, however, local employment did decline and this coincided with a slight, but appreciable decline in both air cargo and sea cargo activity ( -4.3 percent from the year before for air cargo and -3.3 percent in sea cargo). The recession of 1991 was reflected in a 1.6 percent decline in total employment, but air and sea cargo both registered significant gains that year. The national recession of 2001 arrived late (and with less intensity) in Miami. Local employment grew by 1.6 percent during the 2001 recession, but remained virtually unchanged in 2002, as the volume of sea cargo expanded by 5.7 percent while air cargo fell by 6.2 percent that year. This recent historical experience with respect to the correlation between fluctuations in international trade activity and fluctuations in employment is, therefore, mixed.

Table 2: Trends And Cycles In International Cargo And Employment Absolute Change Per Period

\begin{tabular}{|l|c|c|c|c|c|c|}
\hline & \multicolumn{7}{|c|}{ Time Periods } \\
\hline & \multicolumn{3}{|c|}{ Longer Term Trends } & \multicolumn{3}{c|}{ Business Cycles } \\
\hline & $1970-1980$ & $1980-1990$ & $1990-2000$ & $1981-82$ & $1990-91$ & $2001-02 *$ \\
\hline Air Cargo (tons) & 254,750 & 289,351 & 751,676 & $-18,710$ & 30,185 & $-77,384$ \\
\hline Ocean Cargo (tons) & $1,705,783$ & $1,091,767$ & $4,214,009$ & $-91,453$ & 291,347 & 659,424 \\
\hline Employment (jobs) & 259,973 & 162,889 & 203,207 & $-7,984$ & $-17,570$ & $-2,969$ \\
\hline$*$ Change in cargo reflects period from 2000 to mid-2002. \\
Sources: Port of Miami, Miami-Dade Aviation Dept., and U.S. Bureau of Economic Analysis, REIS \\
\hline
\end{tabular}

International merchandise trade shipments affect the local economy by supporting jobs directly involved in the transportation of air and ocean vessel cargo or providing other transportation services along the transportation network (trucking and warehousing). In addition, a significant number of local jobs are found in international trade financing companies. Firms engaged in the transport of international cargo, therefore, form the core of an international merchandise trade cluster in Miami-Dade County, Florida.

Firms that provide international cargo services also require supplies of goods and services from other local firms, and indirectly support employment in other industries through supply-chain (or "backward") linkages. Firms directly engaged in international cargo also provide essential services to firms that require their services to move their products to market (i.e., manufacturing firms engaged in exports or integrated with foreign manufacturing through the globalization of production). These forward (or "demand-chain") linkages also create local employment

\footnotetext{
${ }^{2}$ While the absolute gain in jobs was greater in the 1990s than in the 1980s, the growth rate in employment was actually lower as the County population growth rate decelerated.
} 
opportunities. ${ }^{3}$ The relationships between the core elements of the cluster and its forward and backward linkages are illustrated in Figure 1.

Figure 1:

Miami-Dade County's International Merchandise Trade Cluster

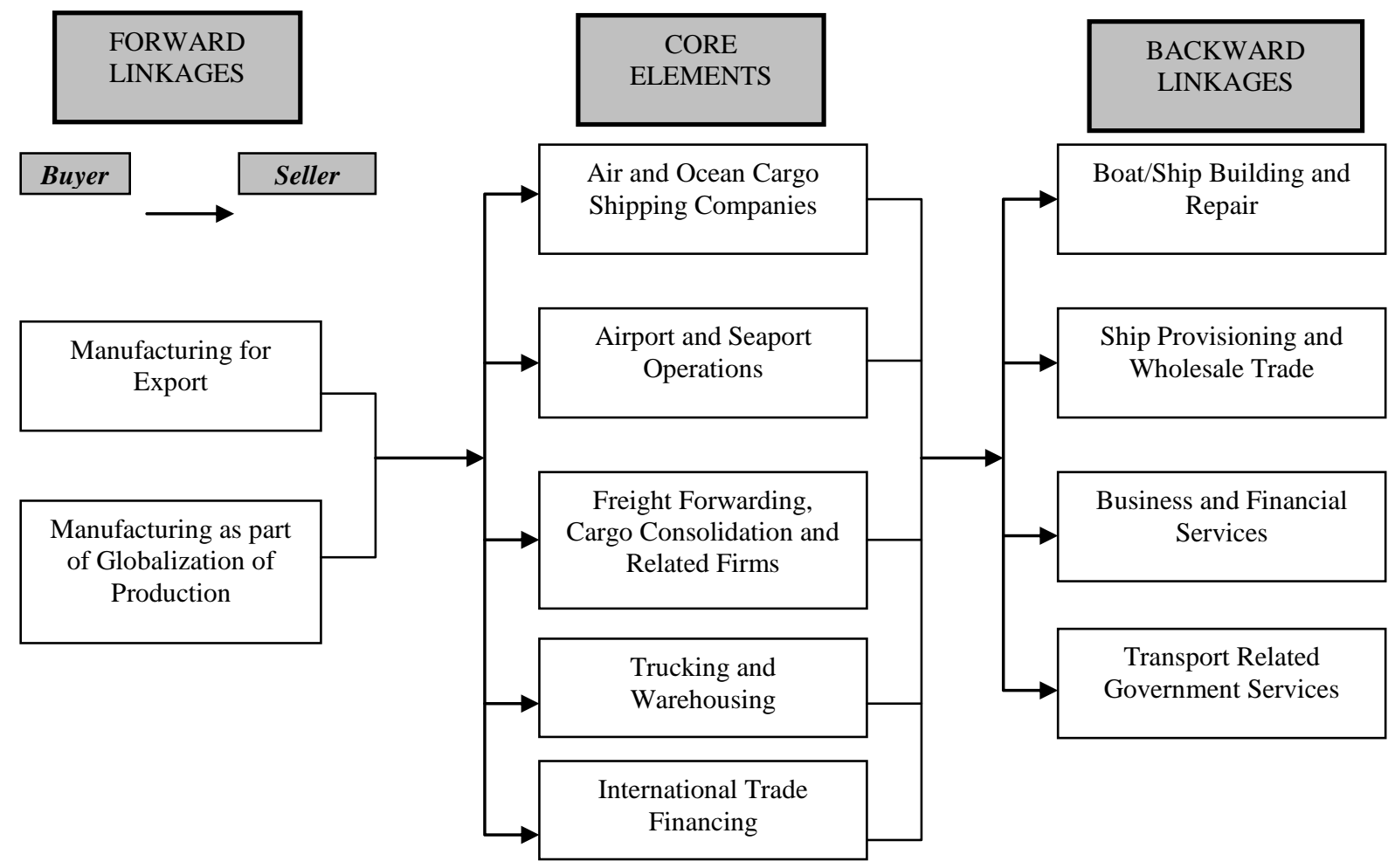

Conceptualizing the economic impact of international trade as involving a cluster of interdependent and mutually supportive business activities is in some respects similar to the methodology suggested by Boske and Cuttino (2003) for estimating the direct economic impact of international trade, where economic activity along the supply chain and transportation corridor are explicitly considered. Boske and Cuttino use a case study approach and trace the various stages involved in moving a product from producer to consumer, calculating the various costs incurred in the production and distribution of the traded good. Boske's and Cuttino's calculation of economic impact, however, stops short of analyzing the indirect and induced impacts using an economic input-output model, although they suggest that their approach can be integrated with such an economic impact model. The approach used in this study, like Boske and Cuttino, attempts to account for local economic impacts of international trade that extend beyond port activity.

The objective of this inquiry is to provide a sound estimate of the economic contribution that the international merchandise trade cluster makes to the broader economy of Miami-Dade County. The first step in this study is to estimate the direct economic impact of international merchandise trade in terms of employment, labor compensation and economic output. We utilize data from the U.S. Census Bureau and an IMPLAN, input-output

\footnotetext{
${ }^{3}$ See M. Porter (1998 and 2000) for a discussion of clusters and their role in economic development and trade.
} 
economic model of Miami-Dade County ${ }^{4}$ to estimate these direct economic impacts. The second step in the analysis is to use the economic model of Miami-Dade County to estimate the indirect economic impacts from supply-chain linkages and the induced economic impacts from consumer spending of payroll to determine the total economic impact of international trade. Our estimates of economic impact rely heavily on secondary data from publicly available sources and are limited, of course, by the quality of that data. The economic impacts of international trade in services (tourism, banking and education being the most important) are not included in this study.

\section{ESTIMATING THE DIRECT ECONOMIC IMPACTS}

The Bureau of Labor Statistics' County Employment and Wages series provides estimates of employees covered by unemployment insurance in the private and public sector of the economy at a high level of industry detail. ${ }^{5}$ Using this series, we identified 12 industries directly associated with the core elements of the international merchandise trade cluster. Since some firms in these industries may also have revenues not directly associated with international trade, it was necessary, therefore, to assign an a priori probability ranking for each industry indicating the likely proportion of business derived from international trade. The CEW series, however, underestimates total industry employment because it only counts employees covered by state or federal unemployment insurance, and thus excludes self-employed, some part-time employees and other exempt workers. ${ }^{6}$ The Bureau of Economic Analysis provides an estimate of local employment that adjusts the BLS employment series to include exempt wage and salary workers. ${ }^{7}$ BEA's estimate of wage and salary employment is approximately 30 percent higher than BLS CEW employment estimates. We, therefore, adjusted the BLS employment estimates by this same percentage to account for workers excluded in the BLS employment estimates in the cluster industries. ${ }^{8}$ Table 1 shows the specific industries that represent the core element of the cluster and the manufacturing industry, their total employment and the estimated proportion of their employment directly associated with international trade. ${ }^{9}$

The estimates of direct employment from local manufacturing activity directly related to international trade represent a significant challenge to the analysis of economic impacts. The Census Bureau's export locator series presents point-of-sale data, or the marketing origin of exports. This presents a special problem in Miami-Dade County with its myriad distributors and manufacturer's representatives that sell products manufactured outside the region to Latin American and Caribbean customers. Miami-Dade County firms shipped \$13.6 billion worth of manufactured exports in 1997 according to the Bureau's export origin series, but the 1997 Economic Census shows the value of all Miami-Dade manufacturing at $\$ 8.6$ billion. It is clear that the export locator series overstates the value of manufactured exports from Miami-Dade manufacturing firms. In addition to the manufacturing of goods for export demand, 14 percent of the value of Miami-Dade manufacturing originates from textiles and apparel. The apparel industry is characterized by globalized production and outsourcing, where U.S. manufacturers are involved in some but not all stages of the production process. Miami-Dade's apparel industry is intimately associated with the importation of apparel from offshore production facilities in the Dominican Republic and Central America. ${ }^{10}$

In the absence of direct information on Miami-Dade manufacturing exports we are left with using our best judgment of the proportion of local manufacturing devoted to foreign demand. If only 10 percent of exports according to the export locator series were to actually be manufactured in Miami-Dade and we include all of the apparel and textile industry production, then one-third of local manufacturing would be associated with international

\footnotetext{
${ }^{4}$ IMPLAN refers to input-output models for planning software developed and marketed by the Minnesota Implan Group, Inc. IMPLAN models have been extensively used in applied regional economic impact studies, and information on the company as well as the software may be found at www.mig.com.

${ }^{5}$ The CEW data series is available for the U.S. Department of Labor at www.bls.gov/cew/home.htm.

${ }^{6}$ This is especially a problem in the case of independent truckers.

${ }^{7}$ BEA employment estimates are available from www.bea.gov/bea/regional/statelocal.htm.

${ }^{8}$ The input-output model used to estimate the economic impacts is calibrated using BEA employment series, and this adjustment was necessary to maintain consistency.

${ }^{9}$ The estimates of the share of revenues resulting from international trade were derived from interviews with a small sample of local businesses in each industry. The sample, however, was not large enough to draw statistical inferences, yet the proportions seem reasonable and consistent with other data. For example, 80 percent of total air cargo from Miami International Airport is designated as international cargo, and 80 of airfreight employment was allocated to international trade. Employment in the cluster elements representing backward linkages is estimated through the economic impact model.

${ }^{10}$ Miami's apparel industry has many similarities to the industry in Los Angeles described by Appelbaum and Christerson (1997).
} 
trade activity. This seems like a reasonable estimate of local manufacturing attributable to international trade until better information regarding local manufacturing of export products becomes available. ${ }^{11}$ Miami-Dade is not a nationally significant manufacturing center and is not known for being a low cost or a high-productivity manufacturing base, and, therefore, its competitive advantage in manufacturing likely originates from its proximity to the Latin American and Caribbean markets either as a source of customers or suppliers.

Table 3: Estimate of Direct Employment in International Merchandise Trade Cluster

\begin{tabular}{|l|c|c|c|c|}
\hline Industry & $\begin{array}{c}\text { NAICS } \\
\text { Code }\end{array}$ & Total Employment & Percent in Int'l Trade & $\begin{array}{c}\text { Direct Cluster } \\
\text { Employment }\end{array}$ \\
\hline Deep sea freight transportation & 483111 & 884 & $100 \%$ & 884 \\
\hline Marine cargo handling & 48832 & 2,963 & $100 \%$ & 2,963 \\
\hline Navigational services to shipping & 48833 & 54 & $100 \%$ & 54 \\
\hline Scheduled freight, air transportation & 481112 & 2,583 & $80 \%$ & 2,066 \\
\hline Nonscheduled air freight, chartering & 481212 & 411 & $80 \%$ & 329 \\
\hline Port and harbor operations & 48831 & 271 & $70 \%$ & 190 \\
\hline Freight transportation arrangement & 4885 & 9,842 & $60 \%$ & 5,905 \\
\hline Packing and crating & 488991 & 136 & $60 \%$ & 82 \\
\hline Support activities for air transportation & 4881 & 6,619 & $40 \%$ & 2,648 \\
\hline Warehousing and storage & 493 & 4,224 & $40 \%$ & 1,690 \\
\hline General freight trucking, long-distance & 48412 & 2,442 & $50 \%$ & 1,221 \\
\hline International Trade Financing & 522293 & 2,630 & $100 \%$ & 2,630 \\
\hline Core Elements & & 33,059 & $63 \%$ & 20,662 \\
\hline Forward Linkages (Manufacturing) & $31-33$ & 71,464 & $33 \%$ & 23,583 \\
\hline Total Direct Employment & & 104,523 & $42 \%$ & 44,245 \\
\hline
\end{tabular}

Our estimate of direct employment positions in the core element of the international merchandise trade cluster is nearly 20,700, while our estimate of direct employment in the forward linkages of this cluster is approximately 23,600 in 2002 . The employment associated with backward linkages is calculated separately using our input-output model of Miami-Dade County.

\section{METHODOLOGY OF CALCULATING IN THE LOCAL ECONOMIC IMPACTS}

Every business activity that operates within the international merchandise trade cluster has the potential to generate positive economic impacts that exceed those directly related to the operation of that business. These "spillover" or multiplier impacts are the result of each business activity's supply relationships with other firms operating within the County (the backward linkages), the proportion of business value added ${ }^{12}$ that accrues to County households in the form of labor and capital income, and the propensity of households to spend income on goods produced within the county.

Economic input-output models explicitly account for inter-industry linkages (supply relationships), the generation of labor and capital income, and the spending of household income in order to estimate the contribution that a particular business or industry makes to the general regional economy. In an input-output model, as an industry experiences an increase in the demand for its products or services, it in turn needs goods and services from its suppliers and must increase its purchases from other industries in the economy.

\footnotetext{
${ }^{11}$ One third is probably a conservative estimate of international trade related manufacturing activity. We did not attempt to conduct a survey of local manufacturers as Barnard (1988) conducted for Madison County, AL because of insufficient resources to conduct a proper and reliable survey.

12 "Value added" refers to the difference between business revenues and the cost of non-labor and non-capital inputs used to produce goods and/or services.
} 
The effect on regional production resulting from successive rounds of inter-industry linkages is referred to as the indirect effect. The resulting increases in regional production also lead to expansions in employment and labor income, and the increases in labor income lead to increases in consumer spending, further expanding sales and production throughout the regional economy. The latter economic impacts are referred to as the induced effects. The successive waves of production, spending and more production result in economic multiplier effects, where the final or total increase in regional production, income and employment, respectively, is larger than the initial (or "direct") increase in production, income and employment. The total economic contribution of an industry, therefore, is comprised of a direct effect, an indirect effect and an induced effect. ${ }^{13}$

The Minnesota IMPLAN Group, Inc. (MIG) provides the software and basic data needed to construct the economic multiplier model we have developed for this study. MIG has been providing regional multiplier models for economic impact analysis since 1985. Models developed using IMPLAN software have been widely used by private- sector and academic economists and by federal, state and local government agencies. The IMPLAN model for Miami-Dade County is based on the latest U.S. input-output tables and income and employment data for MiamiDade from the U.S. Department of Commerce.

A number of previous studies directed at estimating the economic impact of seaports have used a similar approach, although these studies use standard cargo units as the basic indicator of international trade activity and directly tie employment and intermediate input requirements to these cargo units. ${ }^{14}$ The U.S. Maritime Administration has developed an input-output based economic model that U.S. ports frequently used to estimate economic impacts. ${ }^{15}$

\section{ESTIMATES OF ECONOMIC IMPACT}

Computer simulations with our IMPLAN model for Miami-Dade County indicate that international merchandise trade makes a significant contribution to the local economy. The model simulations suggest that approximately 103,000 local jobs could be attributed to international trade in 2002 (approximately 10 percent of total jobs in the County), and international trade generated $\$ 4.0$ billion of compensation to workers (or approximately $\$ 39,000$ per job). Nearly 60 percent of the total employment impact is generated through indirect and induced economic impacts. Approximately one fourth of the total employment impact is found in private services primarily because of induced economic impacts.

The simulations also indicate that international trade contributed $\$ 5.76$ billion of gross regional product to Miami-Dade County in 2002. ${ }^{16}$ This international trade cluster contributed $\$ 7.93$ billion in gross economic output (private sector business revenues plus government expenditures - see Tables 4 and 5). Between 60 and 65 percent of the total economic impacts are contributed by international trade related manufacturing activity, with the remaining balance contributed by international trade transportation activity (including a small proportion by trade financing).

Tables 4 and 5 provide the estimates of economic impact from the core elements of the cluster as well as from the linkages to manufacturing. The manufacturing industry tends to have stronger supply-chain linkages within the county's economy than the supply chain linkages of the industries that comprise the core of the international trade cluster. In addition, compensation per employee in manufacturing also tends to be higher. Both the degree of inter-industry linkages and the relative compensation of employees have a direct impact on the size of the indirect and induced effects, and cause manufacturing activity associated with international trade to have a larger total economic impact per direct employment, than the activity associated with the core elements of the cluster.

\footnotetext{
${ }^{13}$ The basic structure of input-output models used in regional economic impact analysis is described in R. Miller and P. Blair, Input-Output Analysis: Foundations and Extensions (1985) and in W. Schaffer, Regional Impact Models, 1999.

${ }^{14}$ See F. Carstensen, et al, "The economic impact of Connecticut's deep water ports" (2001) for a review of previous port studies using inputoutput models.

${ }^{15}$ The MARAD port economic impact model is available for purchase through the National Technical Information Service at www.ntis.gov.

16 "Gross regional product" is the estimated market value of goods and services produced in Miami-Dade County per year, and is analogous to "gross domestic product" at the national level.
} 
Table 4: Total Economic Impact: Core Elements of International Trade Cluster, 2002

\begin{tabular}{|c|c|c|c|c|c|c|c|c|}
\hline Industry & Direct & Indirect & Induced & Total & Direct & Indirect & Induced & Total \\
\hline & \multicolumn{4}{|c|}{ Employment } & \multicolumn{4}{|c|}{ Gross Economic Output (\$ million) } \\
\hline Core Elements of Cluster & 20,662 & 2,269 & 264 & 23,195 & $2,304.5$ & 287.8 & 28.7 & $2,621.0$ \\
\hline \multicolumn{9}{|l|}{ Other Industries } \\
\hline Agriculture and Mining & 0 & 9 & 91 & 100 & 0.0 & 0.5 & 4.8 & 5.3 \\
\hline Construction & 0 & 79 & 384 & 463 & 0.0 & 5.5 & 49.5 & 55.0 \\
\hline Manufacturing & 0 & 261 & 336 & 597 & 0.0 & 38.9 & 59.9 & 98.8 \\
\hline Transportation, Communications and Utilities & 0 & 757 & 182 & 939 & 0.0 & 82.6 & 33.4 & 116.0 \\
\hline Wholesale and Retail Trade & 0 & 479 & 4,006 & 4,485 & 0.0 & 47.6 & 215.2 & 262.8 \\
\hline Finance, Insurance and Real Estate & 0 & 608 & 695 & 1,303 & 0.0 & 133.2 & 220.0 & 353.2 \\
\hline Private Services & 0 & 4,173 & 5,046 & 9,219 & 0.0 & 283.9 & 302.2 & 586.1 \\
\hline Government Services & $\underline{0}$ & $\underline{82}$ & $\underline{122}$ & $\underline{204}$ & $\underline{0.0}$ & 11.0 & 19.8 & $\underline{30.8}$ \\
\hline \multirow[t]{2}{*}{ Total Impact from Activity of Core Elements } & 20,662 & 8,717 & 11,126 & 40,505 & $2,304.5$ & 891.0 & 933.5 & $4,129.0$ \\
\hline & \multicolumn{4}{|c|}{ Gross Regional Product (\$ million) } & \multicolumn{4}{|c|}{ Compensation to Workers (\$ million) } \\
\hline Core Elements of Cluster & $1,092.8$ & 121.4 & 15.4 & $1,229.6$ & 858.2 & 93.7 & 12.0 & 963.9 \\
\hline \multicolumn{9}{|l|}{ Other Industries } \\
\hline Agriculture and Mining & 0.0 & 0.2 & 2.6 & 2.8 & 0.0 & 0.1 & 1.8 & 1.9 \\
\hline Construction & 0.0 & 3.6 & 15.7 & 19.3 & 0.0 & 3.3 & 13.7 & 17.0 \\
\hline Manufacturing & 0.0 & 16.6 & 21.7 & 38.3 & 0.0 & 12.5 & 14.1 & 26.6 \\
\hline Transportation, Communications and Utilities & 0.0 & 49.8 & 18.7 & 68.5 & 0.0 & 32.6 & 9.7 & 42.3 \\
\hline Wholesale and Retail Trade & 0.0 & 32.5 & 154.8 & 187.3 & 0.0 & 20.0 & 97.1 & 117.1 \\
\hline Finance, Insurance and Real Estate & 0.0 & 78.9 & 153.5 & 232.4 & 0.0 & 42.3 & 34.7 & 77.0 \\
\hline Private Services & 0.0 & 178.1 & 186.8 & 364.9 & 0.0 & 153.8 & 162.3 & 316.1 \\
\hline Government Services & $\underline{0.0}$ & 5.6 & $\underline{8.3}$ & 13.9 & $\underline{0.0}$ & 5.4 & 7.9 & $\underline{13.3}$ \\
\hline Total & $1,092.8$ & 486.7 & 577.5 & $2,157.0$ & 858.2 & 363.7 & 353.3 & $1,575.2$ \\
\hline
\end{tabular}

An employee in the typical manufacturing firm produced $\$ 171,200$ of output in 2002 dollars according to our economic impact model. For each dollar of output produced by the typical manufacturing firm, $\$ 0.64$ of goods and services must be purchased from other firms, and just over half of those purchases (54 percent) are likely to be purchased from within the County. This implies that for each employee hired by the typical manufacturing firm, $\$ 59,100$ of goods and services will be purchased from other local firms. In contrast, the typical employee within the core elements of the cluster produced $\$ 107,250$ of output, requiring the typical firm to purchase $\$ 36,300$ of goods and services from other local businesses.

Labor compensation per worker is about 9 percent higher in manufacturing $(\$ 43,248$ per job) than in the core elements of the international trade cluster ( $\$ 39,845$ per job). The higher wages in manufacturing, combined with strong intra-industry supply relationships within manufacturing and extensive inter-industry ties, result in larger indirect and induced impacts than those observed for the core elements of the international trade cluster.

\section{CONCLUSIONS}

Data inadequacies represent significant challenges in studies estimating the relative importance of an industry cluster to a local economy. This is particularly evident in the analysis of the economic importance of international trade. While published government data series can help to identify the direct employment in the cluster industries, in the absence of reliable primary data sources, researchers must resort to reasonable judgments in apportioning industry activity (employment or direct sales) between international trade and domestic economic activity. Once the direct economic impacts have been identified, regional input-output models become essential tools for estimating the impacts that occur from the production, income and demand interrelationships that characterize the regional economy. 
Table 5: Total Economic Impact: Forward Linkages of International Trade Cluster, 2002

\begin{tabular}{|c|c|c|c|c|c|c|c|c|}
\hline \multirow[t]{2}{*}{ Industry } & Direct & Indirect & Induced & Total & Direct & Indirect & Induced & Total \\
\hline & \multicolumn{4}{|c|}{ Employment } & \multicolumn{4}{|c|}{ Gross Economic Output (\$ million) } \\
\hline Forward Linkages to Local Manufacturing & 23,583 & 4,461 & 1,263 & 29,307 & $4,196.3$ & 793.8 & 224.7 & $5,214.8$ \\
\hline \multicolumn{9}{|l|}{ Other Industries } \\
\hline Agriculture and Mining & 0 & 1,061 & 152 & 1,213 & 0.0 & 58.4 & 8.1 & 66.5 \\
\hline Construction & 0 & 323 & 576 & 899 & 0.0 & 42.6 & 75.9 & 118.5 \\
\hline Transportation, Communications and Utilities & 0 & 1,470 & 964 & 2,434 & 0.0 & 202.6 & 132.8 & 335.4 \\
\hline Wholesale and Retail Trade & 0 & 4,906 & 5,185 & 10,091 & 0.0 & 336.0 & 355.1 & 691.1 \\
\hline Finance, Insurance and Real Estate & 0 & 553 & 1,558 & 2,111 & 0.0 & 129.0 & 363.7 & 492.7 \\
\hline Private Services & 0 & 6,313 & 8,863 & 15,176 & 0.0 & 408.7 & 538.7 & 947.4 \\
\hline Government Services & $\underline{0}$ & 58 & 859 & 917 & 0.0 & 3.9 & 57.7 & 61.6 \\
\hline \multirow[t]{2}{*}{ Total Impact from Forward Linkages } & 23,583 & 19,145 & 19,420 & 62,148 & $4,196.3$ & $1,975.0$ & $1,756.7$ & $7,928.0$ \\
\hline & \multicolumn{4}{|c|}{ Gross Regional Product (\$ million) } & \multicolumn{4}{|c|}{ Compensation to Workers (\$ million) } \\
\hline Forward Linkages to Local Manufacturing & $1,522.7$ & 288.0 & 81.5 & $1,892.2$ & $1,060.3$ & 200.6 & 56.8 & $1,317.7$ \\
\hline \multicolumn{9}{|l|}{ Other Industries } \\
\hline Agriculture and Mining & 0.0 & 29.9 & 4.4 & 34.3 & 0.0 & 19.8 & 2.9 & 22.7 \\
\hline Construction & 0.0 & 14.2 & 25.3 & 39.5 & 0.0 & 12.4 & 22.1 & 34.5 \\
\hline Transportation, Communications and Utilities & 0.0 & 104.3 & 68.4 & 172.7 & 0.0 & 68.0 & 44.6 & 112.6 \\
\hline Wholesale and Retail Trade & 0.0 & 237.6 & 251.1 & 488.7 & 0.0 & 147.0 & 155.4 & 302.4 \\
\hline Finance, Insurance and Real Estate & 0.0 & 89.2 & 251.5 & 340.7 & 0.0 & 23.5 & 66.3 & 89.8 \\
\hline Private Services & 0.0 & 248.8 & 331.2 & 580.0 & 0.0 & 213.0 & 285.6 & 498.6 \\
\hline Government Services & 0.0 & 3.5 & 51.4 & 54.9 & $\underline{0.0}$ & $\underline{3.0}$ & 44.0 & 47.0 \\
\hline Total Impact from Forward Linkages & $1,522.7$ & $1,015.5$ & $1,064.8$ & $3,603.0$ & $1,060.3$ & 687.3 & 677.7 & $2,425.3$ \\
\hline
\end{tabular}

Our estimates indicate that the international merchandise trade activity in Miami-Dade has a significant impact on the local economy. We conservatively estimate that approximately 10 percent of the local economy may be attributed to the activities related to the transportation or manufacture of international goods for export or import. The total economic impacts, moreover, are spread over a broad spectrum of industries, and, therefore, affect broad segments of the workforce.

\section{REFERENCES}

1. Appelbaum, Richard P. and Brad Christerson (1997). "Cheap Labor Strategies and Export-Oriented Industrialization: Some Lessons from the Los Angeles/East Asia Apparel Connection," Journal of Urban and Regional Research, (21:2), pp 202-218.

2. Barnard, Peggy (1988). "Determining the Current and Potential Economic Impact of Exports: The Case of Madison County Alabama," Economic Development Review, (6:3), pp. 54-58.

3. Boske, Leigh and John Cuttino (2003). "Measuring the Economic and Transportation Impacts of MaritimeRelated Trade," Maritime Economics and Logistics, (5), pp 133-157.

4. Carstensen, Fred, W. Lott, S. McMillan and H. Shrestha (2001), "The Economic Impact of Connecticut's Deep Water Ports: An IMPLAN and REMI Analysis." Connecticut Center for Economic Analysis, Dept of Economics, University of Connecticut, Storrs, CT.

5. Miller, Ronald and Peter Blair (1985). Input-Output Analysis: Foundations and Extensions. Englewood Cliffs, NJ: Prentice Hall.

6. Schaffer, William A (1999). Regional Impact Models. Morgantown, WV: Regional Research Institute, West Virginia University.

7. Porter, Michael E. (1998). "Clusters and the New Economics of Competition," Harvard Business Review. November-December.

8. (2000). "Location, Competition and Economic Development: Local Clusters in a Global Economy," Economic Development Quarterly, (14:1), pp 15-35. 